\title{
Quiénes son nuestros colaboradores
}

\author{
About our collaborators
}

\section{Enrique Laval Román}

Médico infectólogo de adultos, miembro fundador de la Sociedad Chilena de Infectología. Pertenece además a la Sociedad Chilena de Historia de la Medicina, habiendo heredado esta afición de su padre Don Enrique Laval Manrique, quien fuera Profesor de esta asignatura y fundador del Museo Nacional de Historia de la Medicina. Después de completar su adiestramiento en el antiguo Servicio de Enfermedades Infecciosas del Hospital Ramón Barros Luco, pronto se incorporó y desempeñó mayoritariamente su carrera asistencial en el Hospital de Enfermedades Infecciosas Prof. Dr. Lucio Córdova L, llegando a ser Subjefe de Servicio y Director de este establecimiento. Paralelamente se desarrolló como docente en la Cátedra de Enfermedades Infecciosas del Profesor Roque Kraljevic con asiento en el mismo hospital, impartiendo educación para las Facultades de Medicina de la Universidad de Chile y Pontificia Universidad Católica. Su producción científica en Infectología refleja su vasta experiencia clínica, la que junto a sus dotes de comunicador le han permitido ser un magnífico maestro para sus discípulos; admiradas son sus lecciones llenas de detalles semiológicos y amenizadas con sabrosas anécdotas para cada tema que él aborda. Participó como Editor Asociado y Ejecutivo de nuestra publicación periódica desde sus primeros volúmenes. Gracias a su profundo conocimiento de la historia médica nacional y a su perseverancia, la Revista Chilena de Infectología ha podido exhibir para sus lectores sorprendentes facetas de nuestro pasado en enfermedades infecciosas.

\section{G. Walter Ledermann Dehnhardt}

Médico microbiólogo e infectólogo pediatra del Hospital Luis Calvo Mackenna, miembro de la Sociedad Chilena de Infectología y activo socio de la Asociación Chilena de Microbiología. Se inició en el Instituto de Salud Pública siendo sucesivamente jefe de la Sección Cepario Nacional en el Departamento de Diagnóstico, Departamento de Adiestramiento, luego de la Sección Vacunas y el Departamento de Inmunología, y culminando como Director de la institución. En el ámbito clínico ha sido miembro y jefe de la Unidad de Infecciosos de su hospital, actualmente dirige la Unidad Clínica de Segunda Infancia y es miembro de la Comisión de Ética de la Investigación del mismo. En su carrera académica ha contribuido a enlazar dos disciplinas antiguamente distantes y paralelas, como son la Microbiología y la Pediatría, y sentó las raíces en nuestro país para comprender la trascendencia clínica de las bacterias "no fermentadoras". Su producción científica le permitió alcanzar el grado de Profesor Agregado de Pediatría de la Universidad de Chile.

Lo identifican sus agudas observaciones en el plano profesional y cotidiano, sus personalísimas lecciones médicas y conferencias magistrales y, particularmente, su erudición literaria que incluye una gran pasión por la historia de la humanidad y, en particular, de la Microbiología y de sus gestores, rasgos todos, que se reflejan nítidamente a través de sus escritos. Leer al Dr. Ledermann es conocer su humor, su profundo sentido crítico y aprender a apreciar el camino trazado por los antiguos de la Medicina. Junto a Enrique Laval ha amenizado nuestra publicación oficial, la Revista Chilena de Infectología, permitiéndonos alternar dos perspectivas y dos estilos para un mismo tema. 